\title{
THE BOY SCOUT FORESTRY CAMP
}

\author{
By Arthur Herbert Richardson, M.A., M.F. \\ Forester in charge of Reforestation, Ontario.
}

$66 \mathrm{C}$ AY Fellows! you may not believe this but over the 24th holiday an-

other chap and myself planted 500 trees." This remark could have been made by anyone of the 450 boys who have taken part in the Scout Forestry Camp held at Angus, Ontario, over the 24th of May holiday on four occasions since 1929.

The Ontario Boy Scout Forestry Camp was inaugurated in 1929. It was the outcome of a desire of a few leaders of the movement in Toronto to give scouts an opportunity to do some practical work in forestry. Consequently, it was decided that the most suitable field for them to enter was that of reforestation and arrangements were made whereby they would have an oppor. tunity to take part in this important work.

As all the tree-planting done by the government is carried on in the spring, advantage was taken of the 24th of May holiday. This day, coming as it does towards the end of the planting season, when the weather is suitable for camping, lends itself well for such a project as it gives the boys at least two days in camp, because in most centres the day just prior to the 24th is celebrated as Empire Day.

Scouts who attend these camps are selected from troops within a reasonable distance from the village of Angus where the camp is held. The boys must be over 14 years of age and not afraid of some hard work. Early in April a circular letter is sent out inviting troops to select a limited number of scouts to participate in the camp. Those selected must register at provincial headquarters, after which they receive complete information regarding the camp. All such details as to who shall go are arranged at Scout headquarters in Toronto, the Forestry Branch simply makes the camp arrangements and supplies the necessary equipment. The scouts themselves, or their parents, or their troop committees, provide transportation to and from the campsite. Each scout brings his own blankets and personal effects, the Forestry Branch supplies tents with wood floors, transportation while in camp, meals, etc.

The boys participating in this work are divided into groups, each one having the name of a tree species such as:-pines, cedars, oaks, maples and elms, etc. In this way they are conveniently arranged into units for treeplanting crews and for games. One large tent provides sleeping quarters for each group, in front of which is the group standard, bearing a six foot shield with the name of the tree represented and the names of all the troops making 
up the group such as 17th Toronto Troop, 1st Barrie Troop, 2nd Penetang Troop, etc.

The camp is in charge of Arthur Paddon, Jr., Field Secretary of the Ontario Council of Boy Scouts, assisted by one or more experienced scoutmasters, and is conducted strictly in accordance with scout camp regulations.

The camp usually commences with supper on the day before the 24th holiday. Well before that eventful hour, however, the tens are pitched in place under the pine trees with pennants and flags adding colour to the scene, and shields and troop names displayed, so that each troop as it arrives will see its billet at a grance and feel perfectly at home. The big dining tent is set with long tables and eats, and the camp chef, decked out in his stiff white coat and hat, is busy directing his helpers for the first meal.

As the afternoon wears on scouts commence to arrive, some by private car, others on foot, some come with bicycles, while many come in truck loads. Immediately upon arrival each scout is asked to register at the headquarters tent. Soon the first meal is served and everyone feels at home and preparations are made for the evening get-together. This takes the form of a platform meeting in one of the spacious buildings at the Forestry Branch Seed Extracting Plant in the village. At this meeting an illustrated address is given describing in a popular way some facts concerning forestry with special reference to tree-planting.

At this meeting also the official camp badge known as the Forestry Camp Toggle, is presented to each boy. This consists of three wooden beads strung on a piece of buckskin, each part of which has a special forestry significance. One bead is made of White Pine, the tree which has meant more to the lumber business of Ontario than any other; the second is White Spruce, the species used so extensively in the manufacture of pulp and paper; and the third is a piece of Jack Pine made from a stick of wood which came from a Jack Pine plantation, the seed of which was gathered in Ontario, extracted in Angus, grown in a government nursery and finally planted on wasteland twenty-one years ago. The buckskin represents the many forms of wild life which inhabit our forests and which disappear when the forests are destroyed by fire. The Toggle bears the words Angus and the year stamped on the centre bead with a steel die. It is worn on the button of the left pocket and has the sanction of Scouting authorities. When you see a scout wearing a Forestry Toggle you know he has attended a forestry camp and has assisted in the important national work of reforestation.

The evening ends with "taps" at nine-thirty.

Breakfast, camp inspection and flag•break over, the main business of the 
next morning commences. After a walk of three-quarters of a mile along the wooded banks of the Nottawasaga river, the mouth of the Pine river is reached, which it is necessary to cross by means of a floating raft. This is capable of carrying twenty-four boys and is popularly known as the May Flower. It is propelled by a nine cylinder boy power engine, (nine empty oil drums), and has become very popular at the camp. Arriving at the planting site just across the river, tree-planting commences. The boys work in pairs, one digging the holes, the other carrying and planting the trees, and all belonging to the one tree species group working as a unit.

At 10.30 a compulsory rest period is imposed, during which the boys are served chocolate bars and lime juice. This is known as "little lunch hour." The planting then continues from 11.00 o'clock until 12.30. The mid-day meal is served at 1.00 o'clock.

At these camps it is not the intention of the Forestry Branch to procure a lot of free labour from the boys without consideration for the recreative side of the outing. In fact, taking the time spent in the camp as a whole, much more time is given to pleasure than to work. At the same time, the old saying "All work and no play makes Jack a dull boy" is carried out and one is sought to balance the other.

The afternoon of the first day is spent in a trip to the government nursery at Midhurst. Here the boys are shown how young trees are raised from seed and brought on for two or three years to the age and size when they are ready for planting. They are also shown plantations of different ages so that they might know what to expect from their own planting work in a few years. The evening of the second day is spent around the camp fire with troop stunts, story-telling and songs.

Tree-planting is the order of the day for the next morning, and the afternoon is again given over to games. In 1929 the second afternoon was spent on a trip to Camp Borden where, through the courtesy of the officers of the Royal Canadian Air Force, the scouts were shown the latest types of aircraft and were permitted to climb into the pilot's seat and try out the different mechanisms used in operating the fastest machines.

On the evening of the second day the scouts put on their uniforms and go on parade, consisting of a concert to which the friends of scouting and the public are invited. At this gathering the principles of scouting are set forth by play, song and pageant and the whole programme is given by the scouts.

Sunday is duly recognized in camp as the Lord's day. A Scouts Own is held, usually in the open under the pine trees, to which the public is again invited. Lunch is served as the closing meal of the camp, and after the distribution of a souvenir bundle of trees which each scout takes home to plant, the camp comes to an end. 